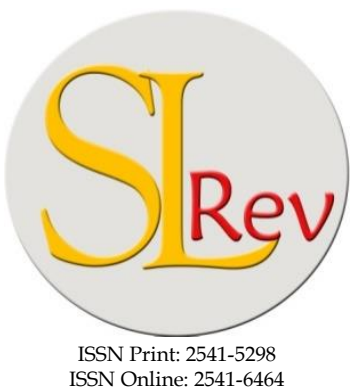

ISSN Online: 2541-6464

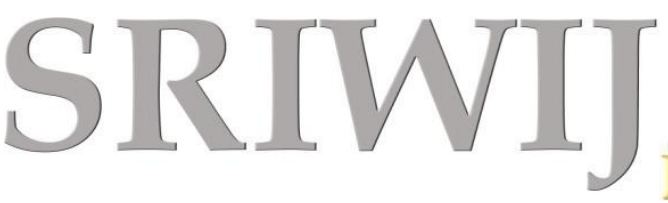

Editorial Office: Faculty of Law, Sriwijaya University, Jalan Srijaya Negara, Palembang, South Sumatra 30139, Indonesia. Phone: +62711-580063Fax: +62711-581179

E-mail: sriwijayalawreview@unsri.ac.id|sriwijayalawreview@gmail.com Website: http://journal.fh.unsri.ac.id/index.php/sriwijayalawreview

\title{
Dispute Settlement between Telkomsel and Indosat: An Analysis on Com- petition of Cellular Operator
}

\author{
Mukti Fajar ND*, Diana Setiawati**, and Yati Nurhayati ${ }^{* * *}$
}

\begin{abstract}
Telecommunication advancement has become a central part of human life brought tight competition among cellular operators. On June 2016, there was a case of business competition between Telkomsel and Indosat (the big Three Cellular operators in Indonesia) that conduct monopoly practice and predatory pricing. In Indonesia, there are two Institutions that maintain business telecommunication and business competition namely Indonesian Telecommunication Regulatory Body (BRTI) has mandated by Law number 36 of 1999 and Business Competition Supervisory Commission (KPPU) by Law Number 5 of 1999. The research aims to know how the government regulates on competition of cellular operator in Indonesia and to know the role of Indonesian Telecommunication Regulatory Body (BRTI) and Business Competition Supervisory Commission (KPPU) to settle the cases on competition of cellular operator (Telkomsel and Indosat cases). The study is normative legal research with statute and case approach, by using juridical qualitative approach. The results of this research are, firstly the analysis of regulation regarding on competition of cellular operator. Secondly the analysis of the role of Indonesian Telecommunication Regulatory Body (BRTI) and Business Competition Supervisory Commission (KPPU) to settle the cases on competition of cellular operator (Telkomsel and Indosat cases) that conduct monopoly practice and predatory pricing, regarding with Law Number 36 of 1999 on Telecommunication and Law Number 5 of 1999 on the Prohibition of Monopolistic Practice and Unfair Business Competition.
\end{abstract}

Keywords: Cellular Operator; Dispute Settlement; Unfair Business Competition.

\section{ARTICLE HISTORY:}

\section{DOI: 10.28946/slrev.Vol3.Iss1.155.pp86-98}

Received: Jul 17, 2018;

Reviewed: Jan 9, 2019;

Accepted: Jan 24, 2019;

Published: Jan 31, 2019;

* Faculty of Law, Universitas Muhammadiyah Yogyakarta, Indonesia and Adjunct Associate Professor, Department of Finance and Economic Law, Asia University Taiwan. E-mail: muktifajar_umy@yahoo.co.id

** Faculty of Law, Universitas Muhammadiyah Yogyakarta, Indonesia. E-mail: diana.setiawati96@gmail.com
**** Lecturer, Faculty of Law, Universitas Islam Kalimantan MAB, Indonesia. E-mail: yatinurhahayati1904@yahoo.com

\section{INTRODUCTION}

The telecommunication industry is engaged in the service industry and is currently the most developed in the last 10 years in Indonesia. The government has regulated telecommunication on Act Number 36 of 1999; this Act gives a significant impact on the development of the telecommunications industry in Indonesia. Telecommunication is a 
strategic industry, and it was important in opening the isolation, improving the quality of education, economic development, social development, environmental conservation, and fulfils the needs of modern lifestyles. Nowadays cellular has become a primary need for people because the function is very important, so people are dependent on telecommunication. ${ }^{1}$

The existence of cellular operator will gave a big impact on the social development in Indonesia. The current number of cellular operator companies has been more than one and has the possibility to lead tight competition between other cellular operators. And in 2010, it was known there were 7 cellular operators in Indonesia, namely: Telkom, XL, Indosat, Axis, three 3, Cellular-8 and Bakrie Telecom. And this time there are three major service provider companies (the big three), namely Telkomsel, Indosat, and XL Axiata. If compared to other countries, the number of cellular operators in Indonesia is the numerous one. Furthermore, in 2014, Alex Sinaga, the President Director of PT. Telkomsel stated that competition in the telecommunication industry has reached saturation position, where there was a Zero Sum Game. This is indicated by the amount of penetration of the telecommunication market in Indonesia, which has more than 200 million customers.

In order to get customers, the cellular operator companies should have the creative strategic on marketing programs, starting with the promotion to the addition of innovative features or programs. Moreover, with the number of cellular operator companies in In-

Uday, R. (2015) Data dan Fakta Industri Selular, Kemegahan vs Kerapuhan. [Online] Available on: http://selular.id/kolom/2015/09/data-dan-faktaindustri-selular-kemegahan-vs-kerapuhan/ (retrieved: September 20, 2016). donesia, it makes the new operators have the spirit to compete with other cellular operator companies. Actually, when compared to other conditions in developed countries, like Australia only has 3 cellular operators company. It would be more effective than in Indonesia which has more than three cellular operator companies.

The competition between cellular operators creates competition on the market share for all of the cellular operator, and there are three (the big three) cellular operator companies which had mastered no less than $75 \%$ market share, and now rake in 125 million customers. XL has 50 million customers while Telkomsel and Indosat have 55 million customers. ${ }^{2}$ Even per July 2015, Tri Hutchinson the directors of Indosat claimed to have 50 million customers. Because of the number of cellular operators, the governments have made the regulation that can regulate the competition among cellular operator companies and can create healthy business competition.

In the middle of the liberalization of the telecommunications industry, the development of cellular operator companies growing rapidly and the competition among operator cellular companies become more competitive. This has led to unfair business competition. June 2016, PT Indosat Tbk Ooredoo complained that PT Telkomsel conducts monopolistic practices in markets outside Java. ${ }^{3}$ This potentially serious accusation does not only drop Telkomsel but it can also impact the Indonesian telecommunications industry. This issue has the damage among the parties

\footnotetext{
Uday, R. Note 1.

Fahmi, R. (2016) Monopoli Telkomsel Benarkah. [Online] Available on: http://koran.bisnis.com/$\mathrm{read} / 20160711 / 251 / 564737 /$ monopoli-telkomselbenarkah/ (retrieved: September 22, 2016).
} 
of cellular operator companies, and the consumers would get the impact too. ${ }^{4}$

The complaint of Indosat to Telkomsel is very serious because Telkomsel assume conducts monopolistic practice. The complaint can be proved by the data obtained in 2012; it is known that Telkomsel which dominate the market amounted to $48.10 \%$ and followed by Indosat amounted to $21.55 \%$, while in the following year, in 2013 Telkomsel is still the market leader. ${ }^{5}$ In 2016 it is known that Telkomsel still dominates the market outside of Java amounted to $80 \%$. Based on the data that is the foundation of Indosat to propose that Telkomsel has conducted monopolistic practice. Moreover, Indosat assumes that Telkomsel has violated Article 17 and 19b of Law Number 5 of 1999 on the prohibition of monopolistic practices and unfair business competition. Articles 17 paragraphs 1 mention that, "Entrepreneurs are prohibited from controlling any production and/or marketing of goods and/or services that can cause monopolistic practices and/or unfair business competition." Meanwhile, article 19b explains, "The prohibition for businessman does not allow some action that could lead to a monopoly practice and unfair business competition". If proven, it will be penalized in accordance with the Act Number 5 of 1999 on the prohibition of monopolistic practices and unfair business Competition. ${ }^{6}$

On the other hand, Indosat issued a new product that is called Freedom Tariff $\mathrm{Rp} 1 /$ second to all operators, and the tariffs are set below the market price that has been

\footnotetext{
4 Herning Bany, R. (2016) Tanggapan Pakar tentang Tudingan Monopoli Telkomsel. [Online] Available on: http//swa.co.id/swa/trends/tanggapan-pakartentang-tudingan-monopoli-telkomsel/ (retrieved: September 22, 2016).

5 Herning Bany, R. Note 4.

6 Herning Bany, R. Note 4.
}

determined by the government. Because of that, Indosat is assumed to have violated Article 20 Law Number 5 of 1999, by conducting predatory pricing practice. ${ }^{7}$ Indosat is doing a campaign with an intention to promote the freedom tariff $\mathrm{Rp} 1 / \mathrm{s}$ program, but the campaign injured Telkomsel. This negative campaign has been successful to make Telkomsel upset because Indosat has put the name of Telkomsel in their promotional banner. This negative campaign action is violating the advertisement ethic.

Muhammad Syarkawi Rauf, the Business Competition Supervisory Commission (KPPU) Chairman, explained both operators have violated the ethics of competition. So the Commission will schedule to call both parties, and then conduct an investigation into the case. Business Competition Supervisory Commission (KPPU) is an independent agency that regardless of the influence and power of the Government and other parties. The function is to oversee the implementation of Law Number 5 of 1999 concerning the prohibition of monopoly practice and unfair business competition. Therefore when there are some cases related to business competition, the commission which has been mandated by law that can settle the cases. ${ }^{8}$

Those cases have led to the attention of the researcher to conduct the further study regarding "Dispute Settlement between Telkomsel and Indosat: An Analysis on Competition of Cellular Operator".

7 Priyanto, S. (2016) Tarif Rp 1/detik Murah atau Predatory Pricing. [Online] Available on: www.kompasiana.com/psukandar/tarif-rp-1-detikmurah-atau-predatory-pricing/ (retrieved: October 14, 2016).

8 The 1999 Law No.5 Article 30 point 2 On the Prohibition of Monopolistic Practice and Unfair Business Competition. 


\section{RESEARCH METHODS}

This research is normative legal research which focuses on a process to find a legal rule, and doctrines of law in order to address the legal issues. ${ }^{9}$ The researchers have collected data from books, reports, legislation (consist of the law no.5 of 1999 on monopoly, law no 36 of 1999 on telecommunication) the internet, and other assorted secondary materials, as cited the references.

This study explores the literature ${ }^{10}$ regarding the regulation on competition of cellular operator and factors that cause on unfair business competition of cellular operator case (Telkomsel and Indosat) and the role of KPPU and BRTI to settle unfair business competition of cellular operator case which is in Conformity with Law Number 05 of 1999 on the prohibition of monopoly practices and Law Number 36 of 1999 on Telecommunication.

The collected data has been analysed by utilizing legislation approach and case approach. ${ }^{11}$ The case between Telkomsel and Indosat on unfair business competition cases are analysed by juridical qualitative approach. Which made to various law or regulation related with the prohibition of monopolistic practice and unfair business competition and telecommunication regulations. Finally, deductive analysed method has been use for formulating the conclusion. In this study, the researcher did not do any justification.

\footnotetext{
9 Noeng Muhadjir, Metodologi Penelitian, Yogyakarta: Rake Sarasin, 2011, p62.

10 Bambang Sugiono, Metodologi Penelitian Hukum, Jakarta: Raja Grafindo Persada, 2015, p52.

11 Mukti Fajar and Yulianto Ahmad, DualismePenelitian Hukum, Yogyakarta: Fakultas Hukum UMY, 2007, p135.
}

\section{ANALYSIS AND DISCUSSION \\ 1. Analysis on how the government regu- lates the competition of cellular opera- tor}

It has been discussed initially that Telecommunication as a strategic industry and provides a huge advantage to entrepreneurs. In Indonesia there are several companies that participate in telecommunication industry we called as cellular operator. In 2016 it was known there were 7 cellular operator namely; Telkom, XL, Indosat, Axis, Three, Cellular-8 and Bakrie Telecom. For every cellular operator has their own strategic marketing program. This number of cellular operator can lead the tight competition. ${ }^{12}$ To control the competition between cellular operators and give legal certainty the government formulated law no 36 of 1999 on telecommunications. As mention in law number 36 of 1999 the activity of cellular operator is supervised by Indonesian Telecommunication Regulatory Body.

Indonesian telecommunication regulatory body is independence body that has authority to controlling the implementation of regulation and to supervised the activity of cellular operator then facilitating dispute settlement between cellular operator and give sanction for the parties that conduct violation. The sanctions are mention in article 46 law number 36 of 1999; (1) administrative sanction (2) license revocation.

Telecommunication industry activity can't be separated with business competition. In Indonesia Business activity must obey the law number 5 of 1999 on prohibition of mo-

12 Didik, P. (2016) Menkominfo Komentari Perang antara Telkomsel dan Indosat [Online] Available on: https://tekno.kompas.com/read/2016/06/18/15290097/Menkominfo.Komentari.Perang.antara.Ind osat.dan.Telkomsel/ (retrieved: September 20,2016) 
nopolistic practice and unfair business competition. The existence law no 5 of 1999 is to create the healthy business competition in Indonesia. Based on article 30 of law no 5 of 1999 give mandate to Business Competition Supervisory Commission (KPPU) as an independent body to supervised the activity of business competition and give sanction for the parties that conduct violation. The sanctions are mention in article 47 law number 5 of 1999; (1) administrative sanction (2) license revocation.

\section{Case Analysis}

\subsection{Legal Analysis of the Violation of Law No. 5 of 1999 by PT. Telkomsel Tbk}

On June 2016, PT Indosat Tbk Ooredoo issued a complaint that PT Telkomsel conducts monopolistic practices in markets outside Java Island. It is a potentially serious accusation, which will not only drop Telkomsel but also will impact the Indonesian telecommunications industry. This issue has the damage among the parties of the cellular operator company, and the consumers will get the impact too. ${ }^{13}$ The complaint can be proven by the data in 2010-2011 by which it is known that Telkomsel dominates the market by amounted to $42 \%$ and followed by Indosat amounted to $21 \%$. The data Proven by this table.

Table 1: Competitive environment on Telecommunication Industry

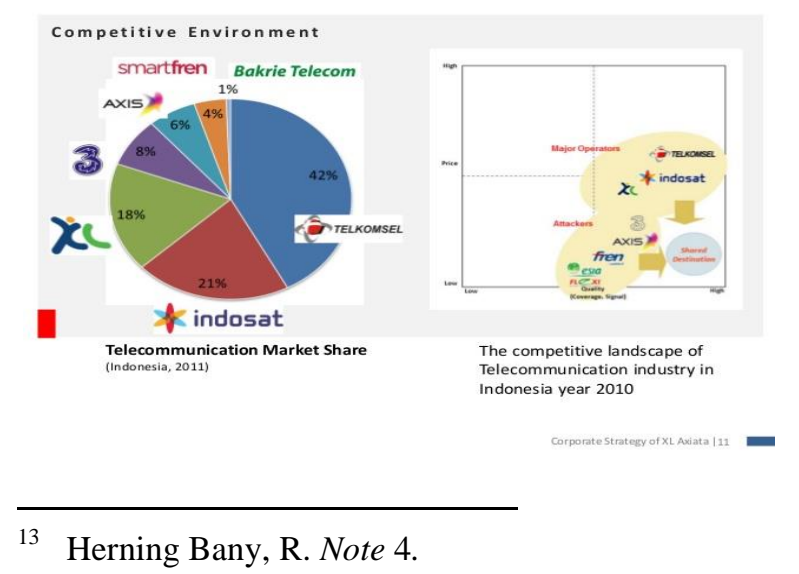

Source: http://swa.co.id/swa/trends/tanggapanpakar-soal-tudingan-monopoli-Telkomsel

Then, in 2016 it is known that Telkomsel has dominated the market outside of Java amounted to $80 \% .{ }^{14} \mathrm{PT}$. Indosat Tbk proposes that PT. Telkomsel Tbk has conducted monopolistic practice because Telkomsel has a dominating market outside Java by more than 50\%. Indosat assumes that Telkomsel has violated Article 17 and 19b of Law Number 5 of 1999 on the prohibition of monopolistic practices and unfair business competition. ${ }^{15}$ Article 19b explains "the prohibition for businessman does not allow some action that could lead to a monopoly practice and unfair business competition". If proven, it will be penalized in accordance with Act Number 5 of 1999 on the prohibition of monopolistic practices and unfair business competition.

Generally, year by year Telkomsel has been increasing not only on their market share but also on the number of customers then follows by Indosat. In a fact, the competitiveness resulted from the use of Telkomsel customer service strategy is more superior compared with that of Indosat's. Additionally, Telkomsel has received many awards for its quality customer service, namely Achieving Exceptional Total Service Quality Satisfaction Service Quality Award 2015, Indonesia Golden Ring Award Best Customer Service in 2015, and Engage Award The Socially Devoted Company for Recognizing and

\footnotetext{
14 Hendra, G. (2013) Telkomsel XL dan Indosat masuk Zona Merah Frekuensi. [Online] Available on: http://www.tribunnews.com/bisnis/2013/06/25/ telkomsel-xl-dan-indosat-masuk-zona-merahfrekuensi/ (retrieved: September 20, 2016).

15 Herning Bany, R. Note 4.
} 
Adapting to the Changing Nature of Customer care, $2015 .^{16}$

On the other hand, Starting from the year 2010 until 2014 Telkomsel continuously has been increasing on the number of customers. The number of Telkomsel Customers it can be proven by this data that showed in the table below:

\section{Table 2: Telkomsel, $\quad$ XL, and Indosat Customers}

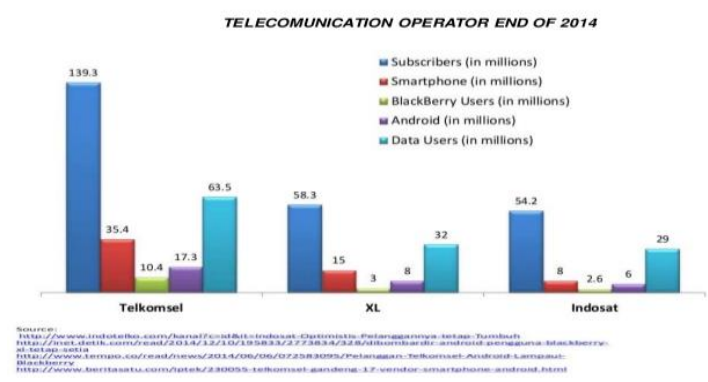

Based on the data above the researcher analysed through the regulation; law number 36 of 1999 on Telecommunication; law 5 of 1999 on Telecommunication and Business Competition Supervisory Commission decision.

First, Based on Article 10 Law Number 36 of 1999 on Telecommunication, monopoly is prohibited action; (1) in operating telecommunications it is prohibited to carry out activities which may cause the occurrence of monopolistic practices and unfair business competition among telecommunications operators. (2) The prohibition referred to in paragraph (1) shall be in accordance with Prevailing statutory regulations. The meaning on Prevailing statutory regulations is Law Number 5 of 1999 on Prohibition of Monop-

16 Dini Turipanam Alamanda, Tamara Fatwa, Grisna Anggadwita, Hani Gita Hayuningtyas, 2017, "Bussines Game that won the Larges Telecomunication Provider in Indonesia," Jurnal Ilmu Hukum Universitas Telkom, 2304-1269, 6(1). pp318. olistic Practices and Unfair Business Competition as well as the implementation regulations were already decided in Business Competition Supervisory Commission decree Number 11 of 2011 stated on Guidelines for the Implementation of Article 17 (Monopoly) Act Law Number 5 of 1999 on Prohibition of Monopolistic Practices and Unfair Business Competition.

Second, Based on Article 17 Law Number 5 of 1999 on the Prohibition of Monopolistic Practice and Unfair Business Competition, Entrepreneurs can be suspected or considered as controlling production and/or marketing or goods and/or services as referred to under Paragraph (1) of this article if: The said goods and/or services do not have substitutions at that time; or (2) It causes other entrepreneurs to not be able to enter business competition for the same type of goods and/or services; or (3)One entrepreneur or one group of entrepreneurs controls more than $50 \%$ (fifty percent) of the marketing share of one type of certain goods or services.

\subsection{Legal Analysis of the Violation of Law Number 5 of 1999 by PT. Indosat}

This problem began in June 2016 when Indosat accuse Telkomsel to conduct Monopoly practice outside Java. Actually, not only Telkomsel assume violate the regulation on the prohibition monopolistic practice and unfair business competition, but Indosat also assumes violate this regulation with conducting a negative campaign and also Predatory pricing. If this action can be proven by KPPU, so Indosat will be punished based on Law No. 5 of 1999.

The first problem is Indosat assumed to conduct predatory pricing. This is because Indosat promotes the new product named Indosat Ooredo freedom free telephone for the 
entire operator with the only $\mathrm{Rp} 1 / \mathrm{s}$ for voice services. ${ }^{17}$ Based on general secretary for Policy Studies and Regulation of Telecommunications, M Ridwan Effendi, said that Indosat Ooredo freedom products are assumed as predatory pricing practice because Indosat sells their product below the cost of production. This obviously could damage the competition in the cellular market. One characteristic of predatory pricing is selling below the price of production to eliminate the competitors. And these actions can damage cellular business competition in Indonesia in the long term.

Based on the financial memo belonging to the three major operators, Telkomsel, Indosat, and XL, in the first quarter of 2016, revenue per minute of voice services to Indosat up to Rp136,7/minute. Meanwhile, Telkomsel amounted Rp168,5/minute, and XL for Rp213,4/min. If Indosat applied the $\mathrm{Rp} 1 / \mathrm{s}$, the price will be Rp60/minute to other operators (of the net) and for the Indosat network (on the net). To apply tariff Rp1/s to all operators, Indosat is expected to bear the loss of Rp190/minute, due to retail tariff under the interconnection charge which is amounted to Rp250/minute. ${ }^{18}$

By lowering tariffs Rp1/Sec for all of the operators, it can be said that Indosat has bad intention to conduct predatory pricing to eliminate other competitors. This condition

17 Hani, N. (2016) Tarif Mahal Telkomsel diserang Indosat apa kata Menkominfo. [Online] Available on: https://www.cnnindonesia.com/teknologi/2016 0617161436-213-139004/tarif-mahal-telkomseldiserang-indosat-apa-kata-menkominfo/ (retrieved: September 20, 2016).

18 Siti, S. (2016) Pengamat Endus Predatory Pricing di Kampanye Rp1/menit Indosat. [Online] Available on: https://www.viva.co.id/arsip/789920pengamat-endus-predatory-pricing-di-kampanyerp1-indosat/ (retrieved: December 8, 2016) has been going on for approximately six months.

Based on Article 20 of Law No. 5/1999 on price fixing is also stipulated in Article 7 of Law No. 5/1999 regarding restrictions on pricing below market prices. However, Article 7 and Article 20 of Law No. 5/1999 will be applied differently by the Commission (KPPU) depending on the facts. Article 7 of Law No. 5/1999 requires agreements with business competitors to set prices below the market price, whereas Article 20 of Law No. $5 / 1999$ does not specify the terms of the agreement. And in this case based on the facts obtained that between Telkomsel and Indosat did not enter into agreements for fixing prices below market prices, so Indosat could be punish under Article 20 of Law No. 5 of 1999 related to a prohibition on predatory pricing ${ }^{19}$

The second problem is the negative campaign conducted by Indosat. Based on the opinion of the Secretary-General and Policy Studies Centre of the Telecommunications Regulatory ITB, M Ridwan Effendi, in Jakarta, Friday, June 24, 2016 he found that the background for the negative campaign conducted by Indosat is the effect of the application of tariff $\mathrm{Rp} 1 / \mathrm{sec}$ which does not meet the target number of customer. Based on the facts, implementation of tariff freedom program $\mathrm{Rp} 1 / \mathrm{s}$ has been running for about five months, but it seems a million customer acquisition plan expected by Indosat is not successful. ${ }^{20}$ So, Indosat held such a negative campaign to all customers. A negative campaign conducted by Indosat with the tariff scheme under the production tariff has led to an unhealthy competition. ${ }^{21}$ So the Business

\footnotetext{
Siti, S. Note 18.

Hani, N. Note 17.

Hani, N. Note 17.
} 
Competition Supervisory Commission Chairman Rauf Syarkawi Commission will analyse the implementation of Indosat Ooredo freedom tariff Rp1/second program.

The poster used at the time of the negative campaign is clearly impolite, and this action is clearly violating the code of ethics on competition, these can action injured other operator cellular especially Telkomsel. ${ }^{22}$ And this action also can impact the consumers. These are the poster that used by Indosat to do the negative campaign:
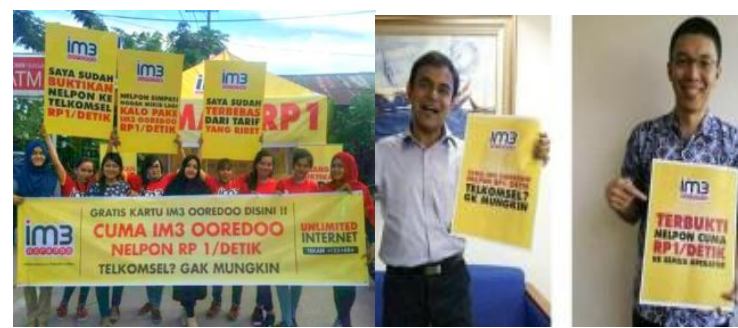

Source:http://www.cnnindonesia.com/teknologi/20160 617161436-213-139004/tarif-mahal-telkomsel-

diserang-indosat-apa-kata-menkominfol

From the poster above, we can see clearly that the negative campaign conducted by Indosat clearly harm the spirit of Law number 5 of 1999 to create a healthy competition. Promotion action should be promoting the product with good intention and fair competition between cellular operators to give choices to the consumer.

Based on the opinion of the Chairman of the Institute for Information Society Development and Empowerment (LPPMI) Kamilov Sagala, he argued that the actions taken by Indosat against Telkomsel are Very unethical. Indosat and Telkomsel have become an overlap between a player and a regulator. This negative Campaigns conducted by In-

22 Susetyo, D. (2016) Sudah Bukan Jamanya lagi Operator Lakukan Kampaye Negatif. [Online] Available on: https://www.cnnindonesia.com/teknologi/20160621155253-213-139834/sudahbukan-zamannya-lagi-operator-lakukankampanye-negatif/ (retrieved: December 8, 2016). dosat is clearly wrong in advertisement ethics. $^{23}$ About the issue of monopoly practice conducted by Telkomsel, actually Indosat should report directly only to the regulator (BRTI), but Indosat even brought the issue to the media in advance, it seems that Indosat wanted to influence public perspective on the lack of Telkomsel service. ${ }^{24}$

\section{The Business Competition Supervisory Commission (KPPU) and Indonesian Telecommunications Regulatory Body (BRTI) Settle the Unfair Business Competition Case of Cellular Operator}

There are two institutions will be able to handle these cases. Related with this cases, In Indonesia has two Institution which one is focusing on maintaining the Telecommunication industry namely Indonesian Telecommunication Regulatory Body (BRTI) and other institution focusing on maintaining the business competition activity namely Business Competition Supervisory Commission (KPPU). These two Institutions will be work together to create a good environmental business competition in the telecommunication industry.

Both Institutions has their own authority that regulates in law number 36 of 1999 on Telecommunication; Telecommunication ministry decree number 31 of 2003 on Indonesian Telecommunication Regulatory Body and law number 5 of 1999 on the prohibition of monopolistic practice and unfair business competition.

Actually, when there are cases on Telecommunication industry the Indonesian Regulatory body has mandated by the law to analyse the case, if the case is related with implementation of telecommunication industry, BRTI can settle the case with give adminis-

$\begin{array}{ll}23 & \text { Susetyo, D. Note } 22 . \\ & \text { Susetyo, D. Note } 22 .\end{array}$ 
trative sanction. If the case is related to the business competition, the case is given to the Business Competition Supervisory Commission (KPPU) to settle/examine the case, but when the case is related to criminal action, the case given to the executor to settle the case, as like as in the penal code, Because BRTI and KPPU didn't have executor function.

\subsection{The Business Competition Superviso- ry Commission (KPPU) Settle the Un- fair Business Competition Case of Cel- lular Operator}

If there is a report letter on the violation of Law Number 5 of 1999, then KPPU should examine that case in order to determine that the parties have violated the regulation or not. The preliminary process takes 30 working days after the report letter is received. In this issue, the Business Competition Supervisory Commission (KPPU) can proceed to the next process if it can prove that the parties have conducted the unfair business competition. In this preliminary process, KPPU may bring witnesses if necessary.

Preliminary process is already starting by calling both parties in advance. On June 24, 2014, the Commission already succeeded in calling both parties for an investigation. The Commission has managed to get information from both sides. This investigation process was represented by Gopprer Panggabean as enforcement director of the Commission. He said that they already received an explanation from both parties, Indosat and Telkomsel.

As an investigation result, it is known that Telkomsel dominance outside of Java has amounted to $80 \% .^{25}$ Based on Law No. 5 of 1999 on the Prohibition of Monopolistic Practices and Unfair Business Competition, it

25 Hendra, G. Note 14 is stated that any parties cannot hold more than $50 \%$ of market share. However, the amount of market share of more than $50 \%$ is seen based on the national scale, not seen from Java or outside Java. While in fact, the market share held nationally by Telkomsel was not more than $50 \%$, but just around $45 \%$; whereas, the rest of the market share was held by other operators.

On the other hand, Indosat applied for the Ooredo freedom program with tariff of $\mathrm{Rp} 1 / \mathrm{sec}$ for all operators, and this tariff is far below the price of production; this can be proven by the financial memo owned by the big three major operators, Telkomsel, Indosat, and XL, in the first quarter of 2016, revenue per minute of voice services to Indosat was Rp. 136,7/min. ${ }^{26}$ Meanwhile, Telkomsel amounted to Rp168,5/min, and XL for Rp. $213,4 / \mathrm{min}$. If Indosat rates apply $\mathrm{Rp} 1 / \mathrm{sec}$, it will result in the price of Rp60/minute to other operators (off the net), and the same thing will happen for Indosat's call numbers (on the net). To apply Rp1 rates to all operators, Indosat is expected to bear the loss of Rp. 190/minute due to retail tariff under the interconnection charge which is amounted to Rp. 250/minute. Based on this fact, Indosat is in violation of Article 20 (predatory pricing) Law Number 5 of 1999.

\subsection{The Indonesian Telecommunications Regulatory Body (BRTI) Settle the Unfair Business Competition Case of Cellular Operator}

Preliminary process is already starting by calling both parties in advance. Monday, June 27, 2016. BRTI has collected some information from Indosat about the truth of the negative campaign conducted by Indosat. Harsyo, the member of BRTI, sees these cases as mild cases, and do not need to impose

26 Hendra, G. Note 14. 
tough sanctions. So, BRTI did not impose hard punishment.

Indonesian Telecommunication Regulatory Body (BRTI) claimed to have dropped a decision to respond to the chaotic between Indosat and Telkomsel. The finalized sanctions warning were posted by Indonesian Telecommunication Regulatory Body to Indosat on Monday, June 27, 2016. According to the Associated General the sanctions that will be given for the company is in the form of a warning because Indonesian Telecommunication Regulatory Body (BRTI) sees that this case of negative campaigning does not require severe sanctions, so BRTI only gives remain letter to Indosat.

\section{CONCLUSION}

Based on the previous discussion, it can be concluded that Telkomsel did not conduct Monopolistic practice. Because regarding Article 19b Law Number 5 of 1999 the amount of $50 \%$ market share is seen based on the national scale, not seen from Java or outside Java. While in fact, the market share held nationally by Telkomsel was not more than $50 \%$, but just around $45 \%$; whereas, the rest of the market share was held by other operators.

For Indosat cases it can be conclude that conducts Predatory Pricing practice. Because based on the analysis of the author, Indosat has done predatory pricing which is prohibited under Article 20 of Law No. 5 of 1999. This is proven by the fact that Indosat Ooredo applied for freedom program with the tariff of $\mathrm{Rp} 1 / \mathrm{sec}$ to all providers is indeed far below the production price. So Indosat will get punish based on article 48 Paragraph 2 which state that Violations to the provisions under Article 5 through 8, Article 15, Articles 20 through 24, and Article 26 of this law is subject to a criminal fine in the amount of at least Rp. 5,000,000,000 (five billion rupiahs) and in the amount of Rp. 25,000,000,000 (twenty-five billion rupiahs) at the most, or imprisonment at a maximum period of 5 (five) months.

The Negative campaign conducted by Indosat is obviously a very unethical thing to do. The negative campaign conducted by Indosat is a clear violation of point 1:20 of the Indonesian advertisement Ethics amendment 2014. Furthermore, BRTI sees this case of negative campaign does not require severe sanctions, so BRTI only gives remain letter to Indosat.

\section{REFERENCES \\ Books}

Prayoga, Ayuda. 1999. Persaingan Usaha dan Hukum yang Mengaturnya di Indonesia. Jakarta: Elips.

Siswanto, Arie. 2002. Hukum Persaingan Usaha. Jakarta Selatan: Ghalia Indonesia.

Sitompul, Asril. 1999. Praktik Monopoli dan Persaingan Tidak Sehat. Bandung: Citra Aditya Bhakti.

Sugiono, Bambang. 2015. Metode Penelitian Hukum. Jakarta: Grafindo Persada.

Blinder, et al. 2001. Monopoly Principle and policy. Chicago: Thomson South-Western.

Lubis, et al. 2009. Hukum Persaingan Usaha Teks dan Konteks. Jakarta: ROV Creative Media.

Fajar, Mukti and Yulianto Achmad. 2007. Dualisme Penelitian Hukum. Yogyakarta: Fakultas Hukum UMY.

Friedman, Milton. 1999. VII: Monopoly and the Social Responsibility of Business and Labor. Chicago: The University of Chicago.

Fuady, Munir. 1999. Hukum Anti Monopoli. Bandung: Citra Aditya Bhakti. 
Fuady, Munir. 1999. Menyongsong era Persaingan Sehat. Bandung: Citra Aditya Bhakti.

Yusuf, Muri. 2014. Metode Penelitian Kualitatif, Kuantitatif dan Gabungan. Jakarta: Prenada Media Group.

Muhadjir, Noeng. 2011. MetodePenelitian. Yogyakarta: Rake Sarasin.

Khemani, R. Syam. 1999. The Objective of Competition policy, Competition Law Policy. Chicago: South-Western Publishing Company.

Usman, Rachmadi. 2004. Hukum Persaingan Usaha di Indonesia. Jakarta: GramediaPustaka.

Sukanto, Soerjono. 1986. Pengantar Penelitian Hukum. Jakarta: Universitas Indonesia Press.

Mergono, Suyud. 2009. Hukum Anti Monopoli. Jakarta: Sinar Grafika.

\section{Journal}

Dini Turipanam Alamanda, Tamara Fatwa, Grisna Anggadwita, Hani Gita Hayuningtyas. 2017. "Business Game that won the Larges Telecommunication Provider in Indonesia" Jurnal Ilmu Hukum Universitas Telkom. 2304-1269. 6 (1).

\section{World Wide Web}

Amal Nur, N (2016) Teori Ini Jelaskan Tudingan Indosat Soal Monopoli Telkomsel, [Online] Available at: http://www.viva.co.id/haji/read/792352-teori-ini-jelaskantudingan-indosat-soal-monopoli-telkomsel, [retrieved: December 5, 2016].

Andi, (2016) Indosat Ganti Nama Jadi Indosat Oredoo. [Online] Available at: https://www.cnnindonesia.com/teknologi/201 51119102759-213-92642/indosat-gantinama-jadi-indosat-oredoo/, [retrieved: September 20, 2016]

Didik, P, [2016] Menkominfo Komentari Antara Telkomsel dan Indosat. [Online] Available at:
komentari-antara-Telkomsel-Indosat/, [retrieved: September 20, 2016].

Fahmy, R. [2016] Monopoli Telkomsel Benarkah. [Online] http://koran.bisnis.com/read/20160711/251/5 64737/monopoli-Telkomsel-benarkah/ [retrieved: September 22, 2016]

Hani, N. (2016) Tarif Mahal TelkomseldiserangIndosatapa kata Menkominfo. [Online] Available at: https://www.cnnindonesia.com/teknologi/20160617161436213-139004/tarif-mahal-telkomsel-diserangindosat-apa-kata-menkominfo/ (retrieved: September 20,2016).

Herning, B. [2016] Tanggapan Pakar Tentang Tudingan Monopoli Telkomsel, [Online] Available at: http://swa.co.id/swa/trends/tanggapan-pakar-soal-tudinganmonopoli-Telkomsel/

[retrieved: September 22, 2016].

Kemas, I. [2016] Kisruh Tarif Rp1/ detik. [Online] Available at: http://techno.okezone.com/read/2016/06/25/207/1425061/kisruh-tarif-rp1-detik/ [retrieved: December 9, 2016].

M.Iqbal. [2016] Dipanggil BRTI Indosat Oredoo soal Dominasi Telkomsel. [Online] Available at: http://selular.id/fokus/2016/06/dipanggil-brtiindosat-ooredoo-soal-dominasi-telkomsel/ [retrieved: December 9, 2016].

Priyanto, S. [2016] Tarif Rp 1 /detik Murah atau Predatory Pricing. [Online] Available at: http://www.kompasiana.com/psukandar/tarifrp-1-detik-murah-atau-predatorypricing_576b669164afbdfb04d8f892/ [retrieved: October 14, 2016]

Rusli, [2015] Indosat Profit Plunges 52.5 pct. [Online] Available at: http://selular.id/kolom/2015/09/data-danfakta-industri-selular-kemegahan-vskerapuhan/ [retrieved: September 20, 2016].

Susetyo, D, [2016] Sudah Bukan Zaman nya Lagi Operator Lakukan Kampanye Negatif. 
[Online] Available at: http://www.cnnindonesia.com/teknologi/201 60621155253-213-139834/sudah-bukanzamannya-lagi-operator-lakukan-kampanyenegatif/ [retrieved: December 8, 2016]

Siti, S, [2016] Pengamat Endus Predatory Pricing di Kampanye Rp 1/ s Indosat. [Online] Available at: http://www.viva.co.id/haji/read/789920pengamat-endus-predatory-pricing-dikampanye-rp1-indosat/

[retrieved: December 8, 2016].

Syakur, U, [2016] Bantah Monopoli ini Alasan Telkomsel Mendominasi di Luar Jawa. [Online] Available at: https://www.merdeka.com/teknologi/bantahmonopoli-ini-alasan-telkomselmendominasi-di-luar-jawa.html/ [retrieved: December 6, 2016].

Uday, R, [2016] Data dan Fakta Industri Seluler, Kemgahan Vs Kerapuhan. [Online] Available at: http://selular.id/kolom/2015/09/data-danfakta-industri-selular-kemegahan-vskerapuhan/ [retrieved: September 20, 2016].

\section{Laws}

The 1999 Law No. 05 on the Prohibition of Monopolistic Practices and Unfair Business Competition.

The 1999 Law No. 36 on Telecommunication.

The 2000 No. 52 on Government Regulation Telecommunication.

The Communication and Information Minister Regulation (Menkominfo) Number1/PER/M.KOMINFO/01/2010 on the date 25 January 2010 on Telecommunication Provider.

The Decision from Minister of Transportation Number KM.21/2001 on Telecommunication Provider which already changed to the Regulation of the Minister of Information and Informatics Number 31/PER/M.KOMINFO/09/2008 on the Third Changes of the Decisions of Minister of Transporta- tion Number KM.21/2001 on Telecommunication Provider.

Business Competition Supervisory Commission Decree (KPPU) Number 1 of 2006 Concerning the Guidelines to settle the case in KPPU.

Business Competition Supervisory Commission Decree (KPPU) Number 01 of 2010 Concerning Dispute Settlement Procedure.

Business Competition Supervisory Commission Decree (KPPU) Number 06 of 2010 Concerning the Guidelines for the Implementation of Article 25 on Abuse of Dominant Position.

Business Competition Supervisory Commission Decree (KPPU) Number 03 of 2011 Concerning the Guidelines for the Implementation of Article 19D on Discrimination Practice.

Business Competition Supervisory Commission Decree (KPPU) Number 04 of 2011 Concerning the Guidelines for the Implementation of Article 5 on price fixing.

Business Competition Supervisory Commission Decree (KPPU) Number 06 of 2011 Concerning the Guidelines for the Implementation of Article 20 on Predatory pricing.

Business Competition Supervisory Commission Decree (KPPU) Number 11 of 2011 Concerning the Guidelines for the Implementation of Article 17 on Monopolistic practice.

Business Competition Supervisory Commission Decree (KPPU) Number 1 of 2006 Concerning the Guidelines to settle the case in KPPU.

The Decision of the Minister of Transportation Number KM. 33/2004 Concerning Supervision of Healthy Competition in the fixed Network and the Basic Telephone Services Provider.

The Decision of the Minister of Transportation NumberKM.4/2001 on the date 16 January 2001 on Determining of the Basic Plant in National Technical of 2000 development 
of National Telecommunication which already changed to the Regulation of the Minister of Information and Informatics Number 09/PER/M.KOMINFO/06/2010 on the dated 9 June 2010 on the six changes of the Decisions from Minister of Transportation Number KM.4/2001 on Determining of the Basic Plant in National Technical of 2000 Development of National Technical. 